\title{
Aspects of manager, portfolio allocation, and fund performance in Brazil
}

\author{
Cláudia Olímpia Neves Mamede Maestri \\ Universidade Federal de Uberlândia, Faculdade de Gestão e Negócios, Uberlândia, MG, Brazil \\ Email: claudiamamede@yahoo.com.br

\section{Rodrigo Fernandes Malaquias} \\ Universidade Federal de Uberlândia, Faculdade de Ciências Contábeis, Uberlândia, MG, Brazil \\ Email: rodrigofmalaquias@ufu.br
}

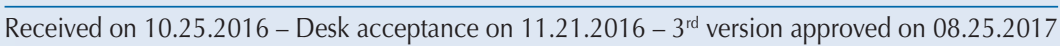

\begin{abstract}
This paper intends to contribute to the literature on investment funds in emerging markets by looking at the performance of multimarket funds in Brazil from a manager perspective. The aim of the paper was to analyze whether some characteristics of investment fund managers, as well as their portfolio holdings, can affect fund performance. In emerging countries both portfolio asset allocation and manager characteristics can help explain differences in the fund performance, which increases the relevance of this study. Therefore, the impact of this research lies in its revealing a significant relationship between riskadjusted return and the portion of portfolios allocated to fixed or variable income, which seems that have not been explored in the context of emerging economies yet. A total of 6,002 multimarket funds were analyzed, covering the period between September 2009 and December 2015, using panel data with robust standard errors clustered by funds. We also employed robust statistics in order to assess some potential biases due to outliers, by analyzing the breakdown point in the estimated models. It should be noted that portfolio composition (allocation of portfolios into variable income and fixed income) was the most important factor in explaining a potential change in the performance of Brazilian multimarket funds. Also important were the effectiveness of the management of these funds, that is, the best risk-adjusted returns were delivered by less experienced managers, funds investing more in fixed income, managers with more funds under management, and larger funds.
\end{abstract}

Keywords: portfolio composition, risk-adjusted return, manager characteristics, emerging markets.

\section{Correspondence address}

Cláudia Olímpia Neves Mamede Maestri

Universidade Federal de Uberlândia, Faculdade de Gestão e Negócios

Avenida João Naves de Ávila, 2121, Bloco 5M, Sala 105 - CEP 38400-902

Campus Santa Mônica - Uberlândia - MG - Brasil 


\section{INTRODUCTION}

On one hand, investors have shown more and more interest in investing their resources in investment funds, seeing the possibility of liquidity, portfolio diversification, resource management by specialized professionals, and superior/abnormal expected returns (Borges \& Martelanc, 2015; Laes \& Silva, 2014; Nanda, Narayanan, \& Warther, 2000; Varga \& Wengert, 2011). In addition, both sophisticated investors (such as market analysts) and non-professional investors have found in funds the possibility of freedom of movement (entry and exit) and access to the diversity of assets in the economy (Funchal, Lourenço, \& Motoki, 2016). Knowledge obtained through financial education increases the importance of saving, and funds represent an alternative with considerable growth in the Brazilian market (Borges \& Martelanc, 2015). On the other hand, investment professionals, for example fund administrators and managers, can use fund performance as marketing in order to attract the attention of investors with the possibilities of maximizing earnings (Gupta \& Jithendranathan, 2012). However, their abilities can also define their investment management style, thus becoming a guide when choosing the fund to invest in (Abinzano, Muga, \& Santamaria, 2010).

In this context, the financial markets of emerging countries stand out in meeting the needs of both investors and fund managers, with them being more receptive (Aggarwal \& Jorion, 2010) and seen as less efficient and providing more chances for managers to deliver excess returns to investors (Huij \& Post, 2011). These chances can derive both from market factors and differentiated styles of allocating resources in the funds' portfolios (Maestri \& Malaquias, 2017).

In addition, the investment fund industry can be seen as an exception to the economic principle that financial agents derive income from having a competitive advantage, since fund managers are among the best paid professionals in society; however, there is still a knowledge gap regarding whether they have the ability to manage money or not (Berk \& Van Binsbergen, 2015). In fact, in the financial markets of Greece, Poland, and India, no evidence has been found of any greater ability to deliver excess returns to investors (Filippas \& Psoma, 2001; Sharma \& Paul, 2015; Swinkels \& Rzezniczak, 2009).

Nonetheless, in Brazil researchers report that some managers present investment skills that generate excess returns (Castro \& Minardi, 2009; Jordão \& Moura, 2011; Rochman \& Eid Jr., 2006). However, these Brazilian studies have basically used market factors [such as Interbank Deposit Certificates (CDIs), the Special System for Settlement and Custody (Selic), the Bovespa Index (Ibovespa), and savings accounts] and performancelinked models (such as French, Carhart, and Jensen). An opportunity is also perceived to evaluate investment portfolios in order to identify whether resource allocation by asset type interferes in fund performance, especially for multimarket funds, which are similar to hedge funds.

Therefore, this knowledge gap regarding the choice of portfolio composition should be noted because depending on the investment policy of the particular fund, hedge fund managers can have more flexibility with regards to where and how to invest resources, including in low liquidity investments (Eling \& Faust, 2010; Jagannathan, Malakhov, \& Novikov, 2010). Thus, fund performance can be influenced by the choice of assets that compose their portfolios and also by some manager characteristics, such as experience, the quantity of funds under management, and their location.

In light of the lack of Brazilian studies concerning the possibility of fund performance being affected by the manager's characteristics in terms of the choice of assets that compose the portfolios, this paper addressed Brazilian multimarket investment funds with the aim of identifying whether some characteristics of their managers and the composition of their portfolios influence the performance of these funds. With this in mind, this paper tends to contribute to the literature by inserting the characteristics of the manager into the choice of assets that compose the portfolios and into the performance of Brazilian multimarket funds, thus contributing towards minimizing the scarcity of research on the abilities of fund managers in emerging markets (Swinkels \& Rzezniczak, 2009).

Based on the results of the research, the main contribution of this study lies in revealing a variable (composition of portfolios in variable income) that helps explain the risk-adjusted return achieved by the funds. This variable presented the highest beta coefficient in the estimated models and was thus shown to be an important piece of information to be considered by investors when selecting funds with better performance indicators. 


\section{THEORETICAL FRAMEWORK}

\subsection{Portfolio Allocation and Fund Performance}

Shawky, Daí, and Cumming (2012) point out that diversification can affect hedge fund performance. They found that funds that diversified into sectors and asset classes presented a positive relationship with performance. In contrast, diversification through investment style and geographical location presented a negative relationship with performance (Shawky et al., 2012).

In addition, the activity of managing resources in fund portfolios with the aim of achieving better returns may be related to the manager's ability (Avramov \& Wermers, 2006; Berk and Van Binsbergen, 2015; Edwards \& Caglayan, 2001; Jagannathan et al., 2010). According to Avramov and Wermers (2006), in the United States of America, the explanation is derived from the effects of the intra- and inter-industry allocation of fund assets, paying attention to the business cycle (economic changes between recessions and expansions), and to the investment sectors. Along these lines, greater performance related to the abilities of managers in Brazil has been shown by Brito (2003), Leusin and Brito (2008), and Malaquias and Eid Jr. (2014), among other academics, who found that some managers add value for investors. For example, Leusin and Brito (2008) note that some fund managers are skilled in investing in variable income and can anticipate the prices of these assets in relation to fixed income ones, thus achieving better returns than passive managers.

Considering an investor's perspective, by studying the variation in funds' exposure to risk over time in the United States of America, Naka and Noman (2017) identified, among other results, that there is a greater fluctuation in (i) US market betas in relation to external market betas and (ii) emerging market betas in relation to developed market betas, which may help investors who seek the diversification benefits of investing in funds. In Australia, Gupta and Jithendranathan (2012) report that investors base their investment decisions on the past performance of actively managed funds and that there is little reaction to the risk between investment categories. This is because the country is dominated by retired fixed income investors, due to federal government policies that oblige workers to contribute a percentage of their salaries to pension funds (Gupta \& Jithendranathan, 2012). Also with regards to fixed income investments, this type of investment also has greater weight in Brazil, as fixed income funds are the biggest group of funds in terms of net equity
(Brazilian Association of Financial and Capital Market Entities - ANBIMA, 2015). Probably, one of the factors that supports this position is the weight of fixed income investments in Brazilian government bonds, which usually remunerate investors with high interest rates and thus attract more interested parties, besides investors believing that government bonds are one of the safest investments in the market (Brière \& Signori, 2013).

At the other extreme to fixed income are high risk investments, such as hedge and multimarket funds (Cumming, Dai, \& Johan, 2015; Mamede \& Malaquias, 2017). Multimarket funds are similar to hedge funds (Malaquias \& Eid Jr., 2013; Mamede \& Malaquias, 2017; Varga \& Wengert, 2011), whose investments are grouped by location and strategy, in which the location refers to the "where" or type of asset - for example, shares, government bonds, currencies, derivatives - and the strategy refers to the "how" or which option - for example, trading, long and short, interest, and currency (ANBIMA, 2015; Fung \& Hsieh, 2002). With this, it is assumed that investors have access to different levels of risk, considering that multimarket funds seek to diversify their portfolios between fixed income and variable income in order to provide better returns. Based on these points, we have the following hypotheses:

$\mathbf{H}_{\mathbf{0}_{-} \mathbf{1}}$ : there is no relationship between portfolio composition and fund performance.

$\mathbf{H}_{1_{-} \text {: }}$ there is a relationship between portfolio composition and fund performance

\subsection{The Manager's Experience and Fund Performance}

According to Bryant (2012), investment funds have objectives to be fulfilled by their managers, ultimately requiring experience, competency, and specific knowledge from them. Thus, an investor who buys assets from an equity fund is really acquiring the manager's expertise in choosing shares that provide better returns (Bryant, 2012). In this sense, the manager's experience can be seen as a measurement of his/her knowledge of the investment fund market (Li, Zhang, \& Zhao, 2011) and becomes a useful sign for funds as it goes beyond the outperformance record and presents a positive and significant correlation with the following year's performance and shows that 
the managers' abilities persist (Ding \& Wermers, 2012).

Thus, the manager's experience can affect the fund's performance, for example due to questions related to the incentive to achieve better performance when the manager is still seeking to establish his/her career in the market; in addition, managers that have recently joined the market may be more concerned about being fired as a result of a low performance indicator (Chevalier \& Ellison, 1999). Less experienced managers may have more incentives to work harder due to the long career that they have ahead of them and they are more willing to assume risks in the search for better performance, in order to minimize their likelihood of being fired because of low returns (Chevalier \& Ellison, 1999; Li, et al., 2011). Although these arguments are present in the construction of one of the hypotheses of this study, it is appropriate to mention that Chevalier and Ellison (1999) recommend caution in their use.

This negative relationship between the manager's experience and the fund's performance was also addressed by Boyson (2003), highlighting that more experienced managers are more conservative because they have more to lose in terms of personal wealth, current income, and reputation. Malaquias and Eid Jr. (2014) indicate that this relationship could be an indication of agency conflicts, given that the manager's experience could reflect specific knowledge of the market in which he/she operates. In addition, Naidenova, Parshakov, Zavertiaeva, and Tomé (2015) identified that the most experienced managers are usually older than the least experienced ones, have generally been recognized by the market, and tend to be more conservative, probably because they continue applying some strategies and routines that were right in the past.

In contrast, there are studies that show a positive relationship between manager experience and performance, such as Gibbons and Murphy (1992), who indicate that managers with less experience in investments assume fewer risks than more experienced ones because the former are more afraid of recording a low performance, compromising their reputation, and losing career opportunities. However, besides the studies that have found a (negative/positive) relationship between the manager's experience and the performance of the funds under his/her management, there are also the authors Switzer and Huang (2007), who identified that the managers' experience does not affect the fund's performance. These facts lead to the following hypotheses:

$\mathbf{H}_{0_{2} \text { : }}$ : there is no relationship between the manager's experience and the fund's performance.
$\mathbf{H}_{12}$ : there is a relationship between the manager's experience and the fund's performance.

\subsection{Number of Funds under Management and Fund Performance}

The number of funds under management can affect the fund's performance because, according to Bryant (2012), the management structure of investment funds (whether a manager manages a single fund or whether he/she manages various funds) can interfere with the investors' wealth due to the effect on the expenses, the number of businesses in the portfolio, and the changes in style and in the fund's performance. One of the author's findings was that the average increase in the abnormal performance is greater for management structures involving multiple funds than for the management of a single fund.

In contrast, $\mathrm{Hu}$ and Chang (2008), $\mathrm{Hu}, \mathrm{Yu}$, and Wang (2012), and Prather, Bertin, and Henker (2004) found a negative relationship between management structures involving multiple funds and fund performance. From the viewpoint of Prather et al. (2004), as the manager tries to manage more funds, he/she loses focus and effectiveness in his/her work. Thus, according to the authors, taking on more funds even surpasses the economy of scale benefit and leads to a negative relationship with the performance of the funds under management. It is understood that analyzing this question in the Brazilian market is also relevant, especially considering the concentration of funds (large quantity) distributed among relatively few administrator companies (Iquiapaza, 2009) and manager companies. In light of the above, we have the hypotheses:

$\mathbf{H}_{\mathbf{0}_{3}}$ : there is no relationship between the number of funds under management and fund performance.

$\mathbf{H}_{1_{\_}}$: there is a relationship between the number of funds under management and fund performance.

\subsection{Manager's Location and Fund Performance}

The region where the manager resides can affect the fund's performance, since home bias, or the tendency to invest disproportionately in companies that are in the investor's country, state, or region, can lead to a diversified portfolio with an inferior position (Cuthbertson, Nitzschea, \& O'Sullivan, 2016). Due to this, investment decisions, whether due to familiarity or access to information, are subject to local bias (Giannetti \& Laeven, 2012; Ivković \& Weisbenner, 2005; Seasholes \& Zhu, 2010; Sialm, Sun, \& Zheng, 2013; Solnik \& Zuo, 2012; Tekçe, Yilmaz, \& Bildik, 2016). 
Likewise, with regards to home bias from a manager perspective, Coval and Moskowitz (1999) found that managers invest more in companies that are geographically close to the funds and earn substantial abnormal returns in their local investments. Malloy (2005) suggests that analysts who are geographically closer to their investments have an information advantage that results in better performance, but creates space for agency problems. Teo (2009) reports that in a risk-adjusted database, those funds with geographical proximity to their investment markets primarily present greater performance (higher alphas) in relation to other funds. Sialm et al. (2013) show that despite the poor performance of the hedge funds in their study sample, the managers have a local advantage (better quality information, better monitoring, or better access to local hedge funds) that leads to a substantial abnormal performance.
Thus, from a manager perspective, it is supposed that a similar situation could occur in Brazil with regards to home bias in terms of local knowledge and information asymmetry between local and non-local managers. For example, because they are at the center of the capital market businesses, managers that work in Rio de Janeiro or São Paulo may have more access to information and invest in more risky portfolios, which in turn can influence the performance of the funds under their management. In light of the studies presented, we have the hypotheses:

$\mathbf{H}_{\mathbf{0}_{-}}$: there is no relationship between the manager's location and the fund's performance.

$\mathbf{H}_{14}$ : there is a relationship between the manager's location and the fund's performance.

\section{METHODOLOGICAL PROCEDURES}

As a sample this study used those Brazilian multimarket funds with monthly data published in Economatica and at the Brazilian Securities and Exchange Commission (CVM), covering 2009 to 2015, and whose variables follow in Table 1. The initial date was September 2009 as this was the first date with data available involving the composition of the portfolios in Economatica, and the final date was December 2015, as this was the most recent period when the database for the study was composed and which enabled the ratio of annual risk-adjusted return to be calculated.

Table 1 Variables used to test the hypotheses

\begin{tabular}{|c|c|c|c|}
\hline Variables and abbreviations & Estimator & Expected relationship & Base study \\
\hline $\begin{array}{l}\text { Performance } \\
\left(\text { Sharpe }_{\text {Ratio }}\right)\end{array}$ & $\begin{array}{l}\text { The annual Sharpe ratio, which is characterized as } \\
\text { a measure of risk-adjusted return and structured } \\
\text { between the mean and stardard deviation of the } \\
\text { rates of excess returns of an asset portfolio. To } \\
\text { calculate the values the net return was used and } \\
\text { the SELIC was used as the risk-free interest rate. }\end{array}$ & Dependent variable & $\begin{array}{c}\text { Ackermann, McEnally, } \\
\text { and Ravenscraft (1999), } \\
\text { Fonseca, Bressan, Iquiapaza, } \\
\text { and Guerra (2007), } \\
\text { Malaquias and Eid Jr. (2013), } \\
\text { Sharpe (1966), and } \\
\text { Titman and Tiu (2011) }\end{array}$ \\
\hline $\begin{array}{l}\text { Portfolio composition } \\
\quad\left(\text { Port.Comp }{ }_{\mathrm{it}}\right)\end{array}$ & $\begin{array}{l}\text { Percentage of investment in each asset type (in } \\
\text { accordance with the Appendix) to compose the } \\
\text { variable income and fixed income portfolios. }\end{array}$ & $\begin{array}{l}\text { Positive for variable income } \\
\qquad\left(\mathrm{H}_{1-1}\right)\end{array}$ & $\begin{array}{l}\text { Naka and Noman (2017) and } \\
\text { Shawky et al. (2012) }\end{array}$ \\
\hline $\begin{array}{l}\text { Manager's experience } \\
\left(\text { Exp.Manager }_{i \mathrm{it}}\right)\end{array}$ & $\begin{array}{l}\text { Number of years since the manager's } \\
\text { registration at the CVM up to } 1 / 31 / 2016 \text {. }\end{array}$ & Negative $\left(\mathrm{H}_{1 \_2}\right)$ & $\begin{array}{c}\text { Boyson (2003), } \\
\text { Chevalier and Ellison } \\
\text { (1999), and } \\
\text { Naidenova et al. (2015), }\end{array}$ \\
\hline $\begin{array}{c}\text { Quantity } \\
(\text { Qt.F.Adm } \\
\text { it })\end{array}$ & $\begin{array}{l}\text { Naperian logarithm of the quantity of funds } \\
\text { administered by the managers monthly in } \\
\text { the period from } 9 / 1 / 2009 \text { to } 1 / 31 / 2016 \text {. } \\
\text { The Naperian logarithm was used to avoid } \\
\text { problems of scale, since the quantity of funds } \\
\text { is highly dispersed in the study's database. }\end{array}$ & Negative $\left(\mathrm{H}_{1 \_3}\right)$ & $\begin{array}{l}\text { Hu and Chang (2008), } \\
\text { Hu et al. (2012), and } \\
\text { Prather et al. (2004) }\end{array}$ \\
\hline $\begin{array}{l}\text { Location } \\
\left(\text { Location }_{\text {it }}\right)\end{array}$ & $\begin{array}{l}\text { Dummy variable that takes the value } 1 \text { for } \\
\text { managers that live in the state of São Paulo } \\
\text { or Rio de Janeiro and } 0 \text { otherwise. }\end{array}$ & Positive $\left(\mathrm{H}_{1 \_4}\right)$ & $\begin{array}{l}\text { Coval and Moskowitz (1999), } \\
\text { Malloy (2005), } \\
\text { Sialm et al. (2013), and } \\
\text { Teo (2009) }\end{array}$ \\
\hline
\end{tabular}


Table 1 Cont.

\begin{tabular}{|c|c|c|c|}
\hline Variables and abbreviations & Estimator & Expected relationship & Base study \\
\hline $\begin{array}{l}\text { Administration fee } \\
\quad\left(\text { Adm. Fee }_{\mathrm{it}}\right)\end{array}$ & $\begin{array}{l}\text { Maximum administration fee } \\
\text { charged annually by the fund. }\end{array}$ & $\begin{array}{l}\text { Negative } \\
\quad \text { (IV) }\end{array}$ & Rochman and Ribeiro (2003) \\
\hline $\begin{array}{l}\text { Performance fee } \\
\quad\left(\text { Perf.Fee }_{i t}\right)\end{array}$ & $\begin{array}{l}\text { Fee related to the fund's investment policy } \\
\text { and calculated using the fund's result, } \\
\text { defined in the model as a dummy variable } \\
\text { and taking the value } 1 \text { for funds that charge } \\
\text { performance fees and } 0 \text { otherwise. }\end{array}$ & $\begin{array}{l}\text { Positive } \\
\text { (IV) }\end{array}$ & $\begin{array}{l}\text { Ackermann et al. (1999), } \\
\text { Malaquias and Eid } \\
\text { Jr. (2014), and } \\
\text { Shukla (2004) }\end{array}$ \\
\hline $\begin{array}{c}\text { Size } \\
\left(\text { Size }_{\mathrm{it}}\right)\end{array}$ & $\begin{array}{l}\text { Naperian logarithm of the funds' average } \\
\text { monthly net equity. The Naperian logarithm } \\
\text { is used to avoid problems of scale, since } \\
\text { the size of the funds, in reais, is highly } \\
\text { dispersed in the study's database. }\end{array}$ & $\begin{array}{l}\text { Positive } \\
\text { (IV) }\end{array}$ & $\begin{array}{l}\text { Castro and Minardi (2009), } \\
\text { Malaquias and Eid } \\
\text { Jr. (2013), and } \\
\text { Rochman and Eid Jr. (2006) }\end{array}$ \\
\hline
\end{tabular}

CVM = Brazilian Securities and Exchange Commission; H1_1 = there is a relationship between fund composition and fund performance; H1_2 = there is a relationship between the manager's experience and fund performance; H1_3 = there is a relationship between the quantity of funds under management and fund performance; H1_4 = there is a relationship between the manager's location and fund performance; SELIC = Special System for Settlement and Custody; IV= independent variables.

Source: Elaborated by the authors (2016).

With regards to the dependent variable "performance", in order to estimate the Sharpe ratio in this study, multimarket funds with at least 11 returns in each year evaluated were selected; that is, there is a Sharpe ratio for each fund in each year. For the purposes of analyzing the robustness of the results, the Sortino ratio was used (Sortino \& Price, 1994; Sortino \& van der Meer, 1991). The Sharpe ratio is among the most widely recognized performance indicators (Varga, 2001) and considers the excess returns provided by the fund, weighted by its volatility. Although the Sortino ratio involves the same assumption, the denominator of its equation only considers the standard deviation of the undesirable returns. The Sortino ratio thus uses the concept of downside risk (or downside deviation); that is, the spread of returns below an acceptable minimum (Eid Jr., Rochman, \& Taddeo, 2005; Fonseca et al., 2007).

In relation to the other variables in the model, for the test variable "portfolio composition", in an attempt to group the investments by similarity and show segmentation between the categories of assets with more or less exposure to risk (Brière \& Signori, 2013; Gupta \& Jithendranathan, 2012), three groups of portfolio types were used: variable income, fixed income, and none, whose classification follows in the Appendix. Just like the dependent variable (Sharpe ratio), these variables were also calculated annually and represented by the mean of the monthly percentage allocated to each one of the categories during the respective year.

With regards to the test variables related to the fund manager, given the difficulty of information involving individual managers, proxies had to be created to measure them (Chevalier \& Ellison, 1999; Malaquias \& Mamede,
2015; Switzer \& Huang, 2007). Thus, the "manager's experience" was calculated in years by the difference between the base date $1 / 31 / 2016$ and the date the company managing the fund was founded. The "quantity" of funds under management was estimated by the quantity of funds administered monthly by the fund management company. The manager's "location" was constructed using the location of the company managing the fund.

With regards to the other variables, administration and performance fees can be used by the investment funds to align the interests of managers and investors (Ackermann et al., 1999; Edwards \& Caglayan, 2001) and signal superior investment skills and better fund performance (Golec, 1996). Thus, in the United States of America, managers who deliver higher excess returns tend to charge higher fees (Edwards \& Caglayan, 2001; Shukla, 2004), which means that the benefits of active management are not directly reaped by the funds' shareholders (Shukla, 2004). In Brazil, Rochman and Ribeiro (2003) found a negative relationship between the administration fee and fund performance, and Malaquias and Eid Jr. (2014) found a positive relationship between the performance fee and the risk-adjusted return of multimarket funds. The last variable studied was the fund's size, given that in developed countries this variable has presented a negative relationship with fund performance (Chen, Hong, Huang, \& Kubik, 2004; Grinblatt \& Titman, 1989; Gupta \& Jithendranathan, 2012; Pollet \& Wilson, 2008), the reason for which may lie in the growth of funds without any increase in the number of assets, which reduces the optimal allocation of resources in their portfolios (Gupta \& Jithendranathan, 2012). However, in Brazil, Castro and Minardi (2009), Malaquias and Eid Jr. (2013), and Rochman and Eid Jr. 
(2006) found a positive relationship between the fund's size and its performance.

With regards to the structure of the variables in the model proposed for the study, equation 1 follows, which enabled an analysis of the hypotheses involving the manager's characteristics, the composition of his/her investment portfolios, and the performance of Brazilian multimarket funds. The meanings of the abbreviations for the variables (and form of measurement) are available in Table 1.

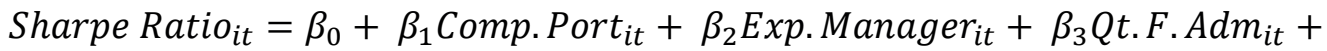

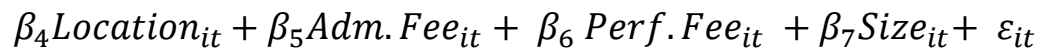

Observing other studies already carried out in Brazil involving fund performance (such as Milan and Eid Jr. [2014]), and similarly to the one carried out by Funchal et al. (2016), the quantitative model to test the hypotheses considers the ordinary least squares regression model in panel format with fixed effects for year and standard errors clustered by fund. This robust procedure was adopted because the standardized residuals of the conventional pooled data regression model did not present a normal distribution in the Shapiro-Wilk test (at a 5\% level of significance). The quantitative tools were employed using the Stata software. We also used robust regressions (Verardi \& Croux, 2009) based on the MM estimator, observing the value of the breakdown point. To evaluate potential multicollinearity problems, the variance inflation factor (VIF) statistic was also used, and with the aim of treating the extreme outliers the variables presented in Table 1 were subjected to the winsorize procedure at $1 \%$. This procedure was employed with the aim of eliminating some potential bias in the coefficients of the models derived from the extreme observations, and at the same time the $1 \%$ level does not substantially alter the characteristics of the data. In order to minimize potential problems related to heteroskedasticity, as previously indicated, the standard errors were clusterized by fund. Additionally, the analysis of the hypotheses was carried out based on the confidence intervals, since they can extend the statistical results to economic results (Ledoit \& Wolf, 2008).

\section{RESULTS}

Table 2 presents the descriptive statistics of this study. It can be seen that in the period from September 2009 to December 2015 the sample of multimarket funds covered 6,002 funds and 25,514 annual observations, with an average Sharpe ratio of 0.225 ; that is, on average the funds presented a higher monthly return than the risk-free rate, in most cases delivering positive returns (extraordinary returns) to their shareholders. 
Table 2 Descriptive statistic of the variables for testing the hypotheses - September/2009 to December/2013

\begin{tabular}{cccccc}
\hline Variables & $\mathbf{n}$ & Mean & SD & Minimum & Maximum \\
\hline Sharpe Ratio & 25,514 & 0.225 & 2.073 & -5.574 & 0.204 \\
\hline Comp.Fixed.Income & 25,514 & 0.204 & 0.300 & 0.000 & 0.000 \\
\hline Comp.Fixed.Income.20 & 25,514 & 0.328 & 0.470 & 0.000 & 1.000 \\
\hline Comp.Fixed.Income.30 & 25,514 & 0.277 & 0.447 & 0.000 & 1.000 \\
\hline Comp.Fixed.Income.40 & 25,514 & 0.232 & 0.422 & 0.000 & 1.000 \\
\hline Comp.Fixed.Income.50 & 25,514 & 0.192 & 0.394 & 0.503 & 1.000 \\
\hline Exp.Manager & 25,514 & 14.307 & 6.649 & 0.000 & 27.119 \\
\hline Qt.F.Adm & 25,514 & 5.140 & 1.749 & 0.000 & 0.000 \\
\hline Location & 25,514 & 0.973 & 0.997 & 0.000 & 1.000 \\
\hline Adm.Fee & 25,514 & 0.747 & 0.401 & 1.00 & 1.000 \\
\hline Perf.Fee & 25,514 & 0.201 & 1.477 & 1.270 & 24.072 \\
\hline Size & 25,514 & 17.374 & &
\end{tabular}

Comp.Fixed.Income = percentage of the portfolio composition involving fixed income; Comp. Fixed.Income.20 = dummy variable, taking 1 for funds whose portfolio percentage in fixed income is greater than 20\%; Comp. Fixed.Income. $30=$ dummy variable, taking 1 for funds whose portfolio percentage in fixed income is greater than 30\%; Comp. Fixed.Income.40= dummy variable, taking 1 for funds whose portfolio percentage in fixed income is greater than $40 \%$; Comp. Fixed.Income.50 = dummy variable, taking 1 for funds whose portfolio percentage in fixed income is greater than 50\%; SD = standard deviation; Exp.Manager = manager's experience in years; Sharpe Ratio = Annual Sharpe Ratio, considering the Special System for Settlement and Custody (SELIC) as the risk-free rate; Location = fund manager's location, taking 1 for location in São Paulo or Rio de Janeiro and 0 otherwise; Qt.F.Adm = Naperian logarithm of the quantity of funds administered by the fund manager; Size $=$ Naperian logarithm of the fund's average net equity; Adm. Fee = the fund's administration fee percentage; Perf. Fee = the fund's performance fee, taking 1 for funds that charge and 0 otherwise.

Source: Elaborated by the authors.

Table 3 presents the results of the hypothesis tests and manager-related variables in the performance of the in terms of the interference of portfolio composition Brazilian multimarket funds.

Table 3 Estimate of the interference of the factors in the risk-adjusted return of the Brazilian multimarket funds

\begin{tabular}{|c|c|c|c|c|c|c|c|c|c|c|c|c|}
\hline \multirow{2}{*}{$\begin{array}{c}\text { Variable } \\
\text { Comp.Fixed.Income }\end{array}$} & \multicolumn{2}{|c|}{ Coefficient } & \multicolumn{2}{|c|}{ CI 95\% } & \multicolumn{2}{|c|}{ Coefficient } & \multicolumn{2}{|c|}{ Coefficient } & \multicolumn{2}{|c|}{ Coefficient } & \multicolumn{2}{|c|}{ Coefficient } \\
\hline & 0.295 & $* * *$ & 0.179 & 0.411 & & & & & & & & \\
\hline Comp.Fixed.Income.20 & & & & & 0.180 & $* * *$ & & & & & & \\
\hline Comp.Fixed.Income.30 & & & & & & & 0.167 & $* * *$ & & & & \\
\hline Comp.Fixed.Income.40 & & & & & & & & & 0.166 & $* * *$ & & \\
\hline Comp.Fixed.Income.50 & & & & & & & & & & & 0.160 & $* * *$ \\
\hline Exp.Manager & -0.026 & $* * *$ & -0.031 & -0.020 & -0.025 & $* * *$ & -0.025 & $* * *$ & -0.025 & $* * *$ & -0.025 & $* * *$ \\
\hline Qt.F.Adm & 0.082 & $* * *$ & 0.057 & 0.107 & 0.081 & $* * *$ & 0.081 & $* * *$ & 0.081 & $* * *$ & 0.080 & $* * *$ \\
\hline Location & -0.011 & & -0.260 & 0.238 & -0.025 & & -0.025 & & -0.022 & & -0.021 & \\
\hline Adm.Fee & -0.110 & $* * *$ & -0.147 & -0.073 & -0.113 & $* * *$ & -0.113 & $* * *$ & -0.113 & $* * *$ & -0.112 & $* * *$ \\
\hline Perf.Fee & -0.075 & * & -0.164 & 0.014 & -0.069 & & -0.071 & & -0.073 & & -0.071 & \\
\hline Size & 0.148 & $* * *$ & 0.127 & 0.170 & 0.151 & $* * *$ & 0.151 & $* * *$ & 0.152 & $* * *$ & 0.153 & $* * *$ \\
\hline
\end{tabular}

Notes: the models consider dummy variables for year and standard errors clusterized by fund. The variance inflation factor (VIF) statistics did not indicate multicollinearity problems among the variables, as all were below 5.0. Coefficient = beta coefficient or regressor parameter; Comp. Fixed.Income = percentage of the portfolio composition related to fixed income; Comp. Fixed.Income. $20=$ dummy variable, taking 1 for funds whose portfolio percentage in fixed income is greater than 20\%; Comp. Fixed.Income.30= dummy variable, taking 1 for funds whose portfolio percentage in fixed income is greater than 30\%; Comp. Fixed.Income.40 = dummy variable, taking 1 for funds whose portfolio percentage in fixed income is greater than 40\%; Comp. Fixed.Income.50 = dummy variable, taking 1 for funds whose portfolio percentage in fixed income is greater than 50\%; Exp.Manager =manager's experience in years; $\mathrm{Cl}=$ confidence interval; Location = fund manager's location, taking 1 for location in São Paulo or Rio de Janeiro and 0 otherwise; Qt.F.Adm =Naperian logarithm of the quantity of funds administered by the fund manager; Adm. Fee = the fund's administration fee percentage; Perf.Fee = the fund's performance fee, taking 1 for funds that charge and 0 otherwise; Size = Naperian logarithm of the fund's average net equity.

***,*** $=p<0.1, p<0.05, p<0.01$, respectively.

Source: Elaborated by the authors. 
The results displayed in Table 3 reveal that in the sample studied covering the period from September 2009 to December 2015 the average percentage allocated to assets classified as fixed income presented a positive relationship with the risk-adjusted return of the funds. However, a positive relationship was expected between a portfolio allocation in mostly variable income and fund performance, since Brazilian multimarket funds are noted as being a category of funds for variable income (Mamede \& Malaquias, 2017). With this, the assumption was that the portfolios with the most exposure to risk (variable income) would be able to deliver a better risk-adjusted return (Naka \& Noman, 2017; Shawky et al., 2012).

Probably one of the reasons for this positive relationship (between portfolio composition in fixed income and risk-adjusted return) lies in the growth fluctuations of the Brazilian interest rate during most of the period studied; that is, the favorable economic environment for investments in fixed income. For example, the annual SELIC rate was $8.65 \%$ in September 2009, $10.66 \%$ in September 2010, and 11.90\% in September 2011 (Brazilian Central Bank, 2016). As described in the methodology of this study, we used MM estimators to evaluate whether the coefficients would not be being influenced by potential outliers. For this, we again estimated all of the models available in Table 3 , using robust regression, and observed that the breakdown point was equal to 0.50 in all five; additionally, the betas of the performance coefficients presented the same sign and level of significance (except for the performance rate variable, which became $1 \%$ significant in all of the models). Thus, due to the results found, hypothesis $\mathrm{H}_{0_{1} 1}$, which proposes that there is no relationship between portfolio composition and multimarket fund performance in Brazil is rejected.

It should be noted that significant changes have occurred in the regulation of Brazilian funds, with the revocation of CVM Instruction n. 409 by CVM Instruction n.555 of 2014 (Comissão de Valores Mobiliários, 2004, 2014). With the aim of evaluating whether these changes have led to some bias in the results obtained with this research, the models whose results are displayed in Table 3 were estimated again, this time excluding the observations from 2014 and 2015 from the sampling period. The results were equivalent in terms of sign and level of significance, except for the performance fee variable in the first model, which was not statistically significant as in the first column of Table 3. Thus, we observed that although there may be some expectation of a significant change in the resource allocation decisions and even in the managers' position as a result of the recent alteration in the regulation of Brazilian investment funds, when observed in a condensed way for the case of the hypotheses analyzed in this study, the effect of the alterations does not appear to invalidate the results of the quantitative models.

In addition, as the criterion employed to classify the assets into fixed income and into variable income may also appear subjective, we carried out a new test by substituting the total percentage allocated to the assets classified as fixed income by the percentage allocated to shares, since this percentage can represent a proxy for investment in variable income. After this, we estimated the model again. We observed that its beta coefficient (of the percentage invested in shares variable) was negative and statistically significant at a level of $1 \%$. We thus have another indication that the percentage allocated to fixed income tends to present a positive effect on the riskadjusted return (indeed the other part allocated to variable income, in this case shares, presented a negative effect). By substituting the percentage invested in equities for the percentage invested in shares in other funds, the beta coefficient was also shown to be negative and significant.

With the aim of adding more elements to the analysis of the robustness of the results, the models whose results are in Table 3 were estimated again, considering three new dependent variables: in the first, Sharpe ratios lower than 0 were substituted by 0 due to the argument that a negative Sharpe ratio perhaps does not represent an adequate measure for decision makers. In the second, funds with a negative Sharpe ratio were excluded from the sample and the third considers the Sortino ratio in substitution of the Sharpe ratio. The difference between the two ratios is in the fact that the Sortino ratio only considers the volatility of the undesirable returns. Table 4 summarizes the results. 
Table 4 Estimate of the interference of the factors in the risk-adjusted return of the Brazilian multimarket funds, considering other measures for performance

\begin{tabular}{|c|c|c|c|c|c|c|}
\hline \multirow{3}{*}{$\begin{array}{c}\text { Variables } \\
\text { Comp.Fixed.Income }\end{array}$} & \multirow{2}{*}{\multicolumn{2}{|c|}{$\begin{array}{c}\text { Negative Sharpe substituted by } 0 \\
\text { Coefficient }\end{array}$}} & \multirow{2}{*}{\multicolumn{2}{|c|}{$\begin{array}{c}\text { Only positive Sharpe } \\
\text { Coefficient }\end{array}$}} & \multirow{2}{*}{\multicolumn{2}{|c|}{$\begin{array}{c}\text { Sortino Ratio } \\
\text { Coefficient } \\
\end{array}$}} \\
\hline & & & & & & \\
\hline & 0.155 & $* * *$ & 0.107 & $*$ & 0.757 & $* * *$ \\
\hline Exp.Manager & -0.011 & $* * *$ & -0.009 & $* * *$ & -0.059 & $* * *$ \\
\hline Qt.F.Adm & 0.011 & $* * *$ & -0.041 & $* * *$ & 0.119 & $* * *$ \\
\hline Location & -0.003 & & -0.060 & & -0.120 & \\
\hline Adm.Fee & -0.072 & $* * *$ & -0.090 & $* * *$ & -0.315 & $* * *$ \\
\hline Perf.Fee & -0.044 & & -0.070 & & -0.354 & $* * *$ \\
\hline Size & 0.051 & $* * *$ & 0.011 & & 0.192 & $* * *$ \\
\hline
\end{tabular}

Notes: the models consider dummy variables for year and standard errors clustered by fund. The variation inflation factor (VIF) statistics did not indicate multicollinearity problems among the variables, as all were below 5.0.

Coefficient $=$ beta coefficient or regressor parameter; Comp. Fixed.Income = percentage of the portfolio composition involving fixed income; Exp. Manager = the manager's experience in years; $\mathrm{Cl}(95 \%)=95 \%$ confidence interval; Location = the fund manager's location, taking 1 for location in São Paulo or Rio de Janeiro and 0 otherwise; Qt.F.Adm = Naperian logarithm of the quantity of funds administered by the fund manager; Size $=$ Naperian logarithm of the fund's average net equity; Adm. Fee = the fund's administration fee percentage; Perf.Fee = the fund's performance fee, taking 1 for funds that charge and 0 otherwise.

***, ${ }^{* * *}=p<0.1, p<0.05, p<0.01$, respectively.

Source: Elaborated by the authors.

As the results in Table 4 indicate, even when the negative values of the Sharpe ratio were substituted by 0 , the percentage allocated to fixed income assets (in accordance with the classification in the Appendix to this study) presented a positive relationship with the risk-adjusted return. In addition, in a subsample that only considers those funds with a positive performance (Sharpe ratio greater than 0 ), the percentage allocated to fixed income continues to be statistically significant, however less so. That is, even in a subsample restricted to funds with good performance in the period, the share of the portfolios in fixed income has a positive relationship with the risk-adjusted return. When another indicator of risk-adjusted return (Sortino ratio) is considered, the results point in the same direction.

The second test variable was the manager's experience, which revealed that less experienced managers obtain a better risk-adjusted return that more experienced managers. This is probably due to the fact that less experienced managers tend to be younger, are overconfident, less risk-averse, and have not yet established a career in the market (Chevalier \& Ellison, 1999; Li et al., 2011). These factors may lead less experienced managers, by linking good fund performance to permanence in employment, to risk more in the search for better returns (Chevalier \& Ellison, 1999; Li et al., 2011). Thus, $\mathrm{H}_{0 \_2}$ ' which proposes that there is no relationship between the manager's experience and the performance of multimarket funds in Brazil, is rejected.

The third test variable was the quantity of funds under management, which revealed that managers who administer more funds deliver a better risk-adjusted return than managers who administer fewer funds. This positive relationship goes against the one highlighted by Hu and Chang (2008), Hu et al. (2012), and Prather et al. (2004), which was also expected for this study. However, it is seen that in Brazil managing multiple funds may not lead to a loss in effectiveness in the services provided by managers, given that they delivered better fund performance. Additionally, managing firms that have a greater number of funds under their management may also be able to optimize management costs and distribute the activities of selecting the best alternatives in the market to carry out investments. Thus, $\mathrm{H}_{0_{3} 3}$, which proposes that there is no relationship between the quantity of funds under management and the performance of multimarket funds in Brazil, is rejected.

The fourth test variable was the managers' location, which did not present a significant relationship with the funds' risk-adjusted return. For this, it is assumed that the home bias due to familiarity or level of information may even exist among fund managing companies in the Rio de Janeiro and São Paulo regions, but in this study the force of this bias did not impact significantly on the funds' performance, which does not corroborate with the studies from Coval and Moskowitz (1999), Malloy (2005), Sialm et al. (2013), and Teo (2009). Thus, $\mathrm{H}_{0_{4}}$ which proposes that there is no relationship between the manager's location and the performance of multimarket funds in Brazil, is not rejected.

Regarding the other independent variables, administration fee presented a negative relationship with the funds' risk-adjusted returns, which according to Rochman and Ribeiro, (2003) may be due to the information asymmetry between investors. The charging of a performance fee did not present a consistent significant 
effect among the different quantitative models estimated, which differs from the findings of Malaquias and Eid Jr. (2014). The size of the funds revealed a positive relationship with the risk-adjusted return, probably because bigger funds are able to save on expenses and operating costs, which is consistent with the studies from Golec (1996), Castro and Minardi (2009), Malaquias and Eid Jr. (2013), and Rochman and Eid Jr. (2006). It should be noted that after the composition of the portfolios, fund size was the variable that best helped explain the risk-adjusted return of the multimarket funds in the sample, based on the criteria considered in this study.

Also in relation to the variables that can affect the risk-adjusted return of investment funds, another way of assessing the results, besides analyzing by the statistical significance of the coefficients of the variables, is to assess the confidence intervals, which can extend the statistical results to economic results (Ledoit \& Wolf, 2008). Thus, as seen in the columns related to confidence interval in Table 3, of the variables used for the empirical analysis in this study, portfolio composition is the variable that most helps in the analysis of risk-adjusted return, since its confidence interval lies between 0.179 and 0.411 .
Therefore, in this data sample and in the quantitative model proposed, considering the manager's portfolio composition helps explain a potential alteration in the average risk-adjusted return of up to 0.295 (this value is greater than the average Sharpe ratio for the sample, which as seen in Table 2 is 0.225 ).

Continuing the analysis by the economic impact of the variables, the second test variable that helps most in the analysis of the risk-adjusted return is size, thus corroborating with the previous studies that consider this variable as relevant for understanding investment fund performance.

In summary, this study, involving the possible influence of the manager's characteristics and of investment portfolio composition on the performance of Brazilian multimarket funds, enabled it to be identified that the effectiveness of active management occurred for less experienced managers who invested more in fixed income, with the management of multiple funds, and with greater size, since these factors offered better risk-adjusted returns for the funds in the period from September 2009 to December 2015.

\section{FINAL REMARKS}

This paper looked at Brazilian multimarket investment funds with the aim of identifying whether some characteristics of their managers and the composition of their portfolios influence their risk-adjusted returns. Thus, this study was able to contribute by highlighting that the variables (about fund manager) that most help explain a potential alteration in performance were portfolio composition and the quantity of funds under management. As far as we were able to analyze in the academic literature from the area of finance, the disclosure of a significant relationship between risk-adjusted return and the portion of portfolios allocated to assets more focused on fixed income or variable income does not yet appear to have been explored, especially in the context of emerging economies, thus revealing this study's main advance.

The paper also made a contribution for investors by highlighting that from the moment they choose the type of multimarket fund they are interested in, knowing the composition of the portfolios of these funds and the characteristics of the manager can represent important information in the search for investments that provide better risk-adjusted returns. For example, based on the analyses carried out in this study, less experienced managers presented (on average) a better risk-adjusted return that more experienced ones. The possible reasons for this negative relationship between performance and experience include the fact that less experienced managers tend to be younger, over-confident, less risk-averse, and have not yet established their careers in the market (Chevalier \& Ellison, 1999; Li, Zhang, \& Zhao, 2011). Thus, these factors may lead less experienced managers, by linking good fund performance to job permanence, to risk more in the search for better results, which is in line with the arguments constructed in the theoretical framework based on previous studies (Chevalier \& Ellison, 1999; Li, Zhang, \& Zhao, 2011).

In summary, based on the sample of 6,002 Brazilian multimarket funds with a minimum period of 11 months of publication in order to form the Sharpe ratio, the results revealed that less experienced managers, those who balanced their portfolios paying attention to fixed income, and who charge a lower administration fee, as well as bigger funds, offered better risk-adjusted returns in the period from September 2009 to December 2015. These results were robust to different forms of analyzing the funds' performance, even when only the winning funds from the sample period were considered.

In relation to the limitations of this study, the first may involve the need to create proxies, due to the lack of 
information in the databases that we consulted, covering personal data related to fund managers, such as the national register of individuals, date of birth, schooling, and specialization in fund management, among others. The second limitation refers to the classification of the assets that compose the portfolios of multimarket funds into variable income and fixed income. As multimarket funds can allocate their portfolios into different asset classes and in the Economatica database these assets are spread over 35 types (as presented in the Appendix to this study), the categorization of assets into variables income and fixed income may have been subjectively defined, especially at times in which the assets were not identified in the guidelines of the CVM or AMBIMA (perhaps due to the recent alterations in the regulation of funds in Brazil mentioned in the results analysis of this study).

The third limitation relates to the use of consolidated information from databases (Economatica database and information on funds accessed from the CVM files for downloading). Although this information contains the data needed to construct the proxies in this study, if there is some limitation in its organization in the databases that provide it, the results of this study are also subject to the same limitations.
The fourth limitation may have been with regards to the omission of variables in the model proposed to explain the performance of Brazilian multimarket funds. Specifically, we understand that the fund's regulation can affect the composition of its portfolios by predetermining the minimum or maximum percentage to be invested in each asset type. Also, it may occur that the manager, faced with the percentages to be fulfilled, opts to work in a more conservative (with allocations close to the defined values) or aggressive (with allocations further from the established limits) way. This limitation opens up the opportunity for new research on the subject.

In addition, with the aim of minimizing the scarcity of research on the abilities of fund managers in emerging markets (Swinkels \& Rzezniczak, 2009), for future research we recommend studying the herd behavior of managers and the way fund managers in Brazil work (individually or in teams). Similarly, other questions could contribute to the literature on emerging market funds, such as net entries and exits of funds, investment funds in fund quotas, private pension funds, and macroeconomic variables, such as the interest rate, inflation rate, and exchange rate variation.

\section{REFERENCES}

Abinzano, I., Muga, L., \& Santamaria, R. (2010). Do managerial skills vary across fund managers? Results using European mutual funds. Journal of Financial Services Research, 38(1), 41-67.

Ackermann, C., McEnally, R., \& Ravenscraft, D. (1999). The performance of hedge funds: risk, return, and incentives. The Journal of Finance, 54(3), 833-874.

Aggarwal, R. K., \& Jorion, P. (2010). The performance of emerging hedge funds and managers. Journal of Financial Economics, 96(2), 238-256.

Associação Brasileira das Entidades dos Mercados Financeiro e de Capitais. (2015). Rankings e estatísticas - Fundos de investimentos - PL e captação. Retrieved from http://portal. anbima.com.br.

Avramov, D., \& Wermers, R. (2006). Investing in mutual funds when returns are predictable. Journal of Financial Economics, 81(2), 339-377.

Banco Central do Brasil. (2016). Histórico das taxas de juros. Retrieved from http://www.bcb.gov.br/Pec/Copom/Port/ taxaSelic.asp.

Berk, J. B., \& Van Binsbergen, J. H. (2015). Measuring skill in the mutual fund industry. Journal of Financial Economics, 118(1), $1-20$.

Borges, E. C., \& Martelanc, R. (2015). Sorte ou habilidade: uma avaliação dos fundos de investimento no Brasil. Revista de Administração, 50(2), 196-207.
Boyson, N. M. (2003). Why do experienced hedge fund managers have lower returns? [Working Paper n. 3]. Purdue University. Retrieved from http://www.edhec-risk.com/research_news/ choice/RISKReview1074252964311707089.

Brière, M., \& Signori, O. (2013). Hedging inflation risk in a developing economy: the case of Brazil. Research in International Business and Finance, 27(1), 209-222.

Brito, N. (2003). Avaliação do desempenho e market timing: o índice de habilidade. Revista Brasileira de Finanças, 1(1), 1-17.

Bryant, L. L. (2012). "Down but not out” mutual fund manager turnover within fund families. Journal of Financial Intermediation, 21(4), 569-593.

Castro, B. R., \& Minardi, A. M. A. F. (2009). Comparação do desempenho dos fundos de ações ativos e passivos. Revista Brasileira de Finanças, 7(2), 143-161.

Chen, J., Hong, H., Huang, M., \& Kubik, J. D. (2004). Does fund size erode mutual fund performance? The role of liquidity and organization. The American Economic Review, 94(5), 12761302.

Chevalier, J., \& Ellison, G. (1999). Are some mutual fund managers better than others? Cross-sectional patterns in behavior and performance. The Journal of Finance, 54(3), 875-899.

Comissão de Valores Mobiliários (2004). Instrução CVM 409, de 18 de agosto de 2004. Dispõe sobre a constituição, a administração, o funcionamento e a divulgação de 
informações dos fundos de investimento. Retrieved from http://www.cvm.gov.br.

Comissão de Valores Mobiliários (2014). Instrução CVM 555 de 17 de dezembro de 2014. Dispõe sobre a constituição, a administração, o funcionamento e a divulgação de informações dos fundos de investimento. Retrieved from http://www.cvm.gov.br.

Coval, J. D., \& Moskowitz, T. J. (1999). Home bias at home: local equity preference in domestic portfolios. The Journal of Finance, 54(6), 2045-2073.

Cumming, D., Dai, N., \& Johan, S. (2015). Are hedge funds registered in Delaware different? Journal of Corporate Finance, 35(C), 232-246.

Cuthbertson, K., Nitzsche, D., \& O’Sullivan, N. (2016). A review of behavioural and management effects in mutual fund performance. International Review of Financial Analysis, 44(C), 162-176.

Ding, B., \& Wermers, R. (2012). Mutual fund performance and governance structure: the role of portfolio managers and boards of directors. [unpublished Working Paper]. State University of New York. Retrieved from https://papers.ssrn. com/sol3/papers.cfm?abstract_id=2207229.

Edwards, F. R., \& Caglayan, M. O. (2001). Hedge fund performance and manager skill. Journal of Futures Markets, 21(11), 1003-1028.

Eid, W., Jr., Rochman, R. R., \& Taddeo, M. (2005). Medidas de desempenho de fundos considerando risco de estimação. Retrieved from http://bibliotecadigital.fgv.br/dspace/ handle/10438/15558.

Eling, M., \& Faust, R. (2010). The performance of hedge funds and mutual funds in emerging markets. Journal of Banking \& Finance, 34(8), 1993-2009.

Filippas, N. D., \& Psoma, C. (2001). Equity mutual fund managers performance in Greece. Managerial Finance, 27(6), 68-75.

Fonseca, N. F., Bressan, A. A., Iquiapaza, R. A., \& Guerra, J. P. (2007). Análise do desempenho recente de fundos de investimento no Brasil. Contabilidade Vista \& Revista, 18(1), 95-116.

Funchal, B., Lourenço, D., \& Motoki, F. Y. S. (2016). Sofisticação dos investidores, liberdade de movimentação e risco: um estudo do mercado brasileiro de fundos de investimento em ações. Revista de Contabilidade e Organizações, 10(28), 45-57.

Fung, W., \& Hsieh, D. A. (2002). Risk in fixed-income hedge fund styles. The Journal of Fixed Income, 12(2), 6-27.

Giannetti, M., \& Laeven, L. (2012). The flight home effect: evidence from the syndicated loan market during financial crises. Journal of Financial Economics, 104(1), 23-43.

Gibbons, R., \& Murphy, K. J. (1992). Optimal incentive contracts in the presence of career concerns: theory and evidence. The Journal of Political Economy, 100(3), 468-505.

Golec, J. H. (1996). The effects of mutual fund managers' characteristics on their portfolio performance, risk and fees. Financial Services Review, 5(2), 133-147.

Grinblatt, M., \& Titman, S. (1989). Mutual fund performance: an analysis of quarterly portfolio holdings. Journal of Business, 62(3), 393-416.

Gupta, R., \& Jithendranathan, T. (2012). Fund flows and past performance in Australian managed funds. Accounting Research Journal, 25(2), 131-157.
Hu, J. L., \& Chang, T. P. (2008). Decomposition of mutual fund underperformance. Applied Financial Economics Letters, 4(5), 363-367.

Hu, J. L., Yu, H. E., \& Wang, Y. T. (2012). Manager attributes and fund performance: evidence from Taiwan. Journal of Applied Finance and Banking, 2(4), 85-101.

Huij, J., \& Post, T. (2011). On the performance of emerging market equity mutual funds. Emerging Markets Review, 12(3), 238-249.

Iquiapaza, R. A. (2009). Performance, captação e foco das famílias de fundos de investimento (Ph.D. Thesis). Universidade Federal de Minas Gerais, Belo Horizonte.

Ivković, Z., \& Weisbenner, S. (2005). Local does as local is: information content of the geography of individual investors' common stock investments. The Journal of Finance, 60(1), 267-306.

Jagannathan, R., Malakhov, A., \& Novikov, D. (2010). Do hot hands exist among hedge fund managers? An empirical evaluation. The Journal of Finance, 65(1), 217-255.

Jordão, G. A., \& Moura, M. L. (2011). Performance analysis of Brazilian hedge funds. Journal of Multinational Financial Management, 21(3), 165-176.

Laes, M. A., \& Silva, M. E. (2014). Performance of mutual equity funds in Brazil - A bootstrap analysis. Economia, 15(3), 294306.

Ledoit, O., \& Wolf, M. (2008). Robust performance hypothesis testing with the Sharpe ratio. Journal of Empirical Finance, 15(5), 850-859.

Lee, J. S., Yen, P. H., \& Chen, Y. J. (2008). Longer tenure, greater seniority, or both? Evidence from open-end equity mutual fund managers in Taiwan. Asian Academy ov Management Journal of Accounting \& Finanance, 4(2), 1-20.

Leusin, L. D., \& Brito, R. D. (2008). Market timing e avaliação de desempenho dos fundos brasileiros. Revista de Administração de Empresas, 48(2), 22-36.

Li, H., Zhang, X., \& Zhao, R. (2011). Investing in talents: manager characteristics and hedge fund performances. Journal of Financial and Quantitative Analysis, 46(1), 59-82.

Maestri, C. O. N. M., \& Malaquias, R. F. (2017). Exposição a fatores de mercado de fundos de investimentos no Brasil. Revista Contabilidade \& Finanças, 28(73), 61-76.

Malaquias, R. F., \& Eid, W., Jr. (2013). Eficiência de mercado e desempenho de fundos multimercados. Revista Brasileira de Finanças, 11(1), 119-142.

Malaquias, R. F., \& Eid, W., Jr. (2014). Multimarket funds: performance, performance determinants and moderator effect. Revista de Administração Mackenzie, 15(4), 135-163.

Malaquias, R. F., \& Mamede, S. P. N. (2015). Efeito calendário e finanças comportamentais no segmento de fundos multimercados. Revista de Administração Contemporânea, 19 (número especial), 98-116.

Malloy, C. J. (2005). The geography of equity analysis. The Journal of Finance, 60(2), 719-755.

Mamede, S. D. P. N., \& Malaquias, R. F. (2017). Monday effect in Brazilian hedge funds with immediate redemption. Research in International Business and Finance, 39 (parte A), 47-53. 
Milan, P. L. A. B., \& Eid, W., Jr. (2014). Elevada rotatividade de carteiras e o desempenho dos fundos de investimento em ações. Revista Brasileira de Finanças, 12(4), 469-497.

Naidenova, I., Parshakov, P., Zavertiaeva, M., \& Tomé, E. (2015). Look for people, not for alpha: mutual funds success and managers intellectual capital. Measuring Business Excellence, 19(4), 57-71.

Naka, A., \& Noman, A. (2017). Diversification of risk exposure through country mutual funds under alternative investment opportunities. The Quarterly Review of Economics and Finance, 64 (C), 215-227.

Nanda, V., Narayanan, M. P., \& Warther, V. A. (2000). Liquidity, investment ability, and mutual fund structure. Journal of Financial Economics, 57(3), 417-443.

Pollet, J. M., \& Wilson, M. (2008). How does size affect mutual fund behavior? The Journal of Finance, 63(6), 2941-2969.

Prather, L., Bertin, W. J., \& Henker, T. (2004). Mutual fund characteristics, managerial attributes, and fund performance. Review of Financial Economics, 13(4), 305-326.

Rochman, R. R., \& Eid, W., Jr. (2006). Fundos de investimento ativos e passivos no Brasil: comparando e determinando os seus desempenhos. Anais do Encontro Nacional da Associação Nacional de Pós-Graduação e Pesquisa em Administração, Salvador, BA, Brasil, 30.

Rochman, R. R., \& Ribeiro, M. P. (2003). A Relação entre a estrutura, conduta e desempenho da indústria de fundos de investimento: um estudo de painel. Anais do Encontro Nacional da Associação Nacional de Pós-Graduação e Pesquisa em Administração, Atibaia, SP, Brasil, 27.

Seasholes, M. S., \& Zhu, N. (2010). Individual investors and local bias. The Journal of Finance, 65(5), 1987-2010.

Sharma, P., \& Paul, S. (2015). Testing the skill of mutual fund managers: evidence from India. Managerial Finance, 41(8), 806-824.

Sharpe, W. F. (1966). Mutual fund performance. The Journal of Business, 39(1), 119-138.

Shawky, H. A., Dai, N., \& Cumming, D. (2012). Diversification in the hedge fund industry. Journal of Corporate Finance, 18(1), 166-178.
Shukla, R. (2004). The value of active portfolio management. Journal of Economics and Business, 56(4), 331346.

Sialm, C., Sun, Z., Zheng, L. (2013). Home bias and local contagion: evidence from funds of hedge funds. [Working Paper n. 19,570]. National Bureau of Economic Research. Retrieved from http://www.nber.org/papers/w19570.

Solnik, B., \& Zuo, L. (2012). A global equilibrium asset pricing model with home preference. Management Science, 58(2), 273-292.

Sortino, F. A., \& Price, L. N. (1994). Performance measurement in a downside risk framework. The Journal of Investing, 3(3), 59-64.

Sortino, F. A., \& van der Meer, R. (1991). Downside risk. The Journal of Portfolio Management, 17(4), 27-31.

Swinkels, L., \& Rzezniczak, P. (2009). Performance evaluation of Polish mutual fund managers. International Journal of Emerging Markets, 4(1), 26-42.

Switzer, L. N., \& Huang, Y. (2007). How does human capital affect the performance of small and mid-cap mutual funds? Journal of Intellectual Capital, 8(4), 666-681.

Tekçe, B., Yılmaz, N., \& Bildik, R. (2016). What factors affect behavioral biases? Evidence from Turkish individual stock investors. Research in International Business and Finance, 37, 515-526.

Teo, M. (2009). The geography of hedge funds. Review of Financial Studies, 22(9), 3531-3561.

Titman, S., \& Tiu, C. (2011). Do the best hedge funds hedge? Review of Financial Studies, 24(1), 123-168.

Varga, G. (2001). Índice de Sharpe e outros indicadores de performance aplicados a fundos de ações brasileiros. Revista de Administração Contemporânea, 5(3), 215-245.

Varga, G., \& Wengert, M. (2011). A indústria de fundos de investimentos no Brasil. Revista de Economia e Administração, 10(1), 66-109.

Verardi, V., \& Croux, C. (2009). Robust regression in Stata. The Stata Journal, 9(3), 439-453. 
Appendix Types of assets that compose the funds' portfolios according to the classification in Economatica and the reclassification of the composition of the portfolios in variable income and fixed income

\begin{tabular}{|c|c|c|}
\hline Sequence & Type of investment in the portfolio - Economatica & Type of income \\
\hline 1 & Shares & Variable \\
\hline 2 & Brazilian depositary receipt & Variable \\
\hline 3 & Transferable securities certificate or receipt & Fixed \\
\hline 4 & Fund quotas & Variable \\
\hline 5 & Debentures & Fixed \\
\hline 6 & Time deposit and other financial institution securities & Fixed \\
\hline 7 & Differential swap payable & Variable \\
\hline 8 & Differential swap recievable & Variable \\
\hline 9 & Quick assets & None \\
\hline 10 & Options on gold spot & Fixed \\
\hline 11 & Stock loans and MS granted & Variable \\
\hline 12 & Stock loans and MS recieved & Variable \\
\hline 13 & Investment abroad & Variable \\
\hline 14 & Futures market - buy position & Variable \\
\hline 15 & Futures market - sell position & Variable \\
\hline 16 & Buy options - holder position & Variable \\
\hline 17 & Buy options - issuer position & Variable \\
\hline 18 & Non rev options - holder position & Variable \\
\hline 19 & Non rev options - issuer position & Variable \\
\hline 20 & Sell options - holder position & Variable \\
\hline 21 & Sell options - issuer position & Variable \\
\hline 22 & Repurchase agreements & Variable \\
\hline 23 & Other MV reg at CVM obj of pub & Variable \\
\hline 24 & Other privately offered sec & Variable \\
\hline 25 & Other investments & None \\
\hline 26 & Other pass and coll ops & None \\
\hline 27 & Term - purchases receiveable & Variable \\
\hline 28 & Term - work for purchase to pay & Variable \\
\hline 29 & Term - work for sale to deliver & Variable \\
\hline 30 & Term - sales to receive & Variable \\
\hline 31 & Private credit securities & Fixed \\
\hline 32 & Securities linked to agrobusiness & Fixed \\
\hline 33 & Public bonds & Fixed \\
\hline 34 & Amounts payable & None \\
\hline 35 & Amounts recievable & None \\
\hline
\end{tabular}

$C V M=$ Brazilian Securities and Exchange Commission; $M S=$ marketable securities; $M V=$ market value .

Source: Elaborated by the authors (2016) 